\title{
Pro-gastrin Releasing Peptide Measurement
}

National Cancer Institute

\section{Source}

National Cancer Institute. Pro-gastrin Releasing Peptide Measurement. NCI Thesaurus. Code C156523.

The determination of the amount of pro-gastrin releasing peptide present in a sample. 